the periphery of the cell. After the exchange of AMP against ATP and of calcium-free calmodulin against calcium-loaded calmodulin the ATPase complex is workable again.

Obviously, the energy transfer via calcium has the advantage that in case of emergency needs great amounts of free energy can be made available in a short time independently of the ATP supply. This is done by flushing calcium-free calmodulin produced by continuous pumping and stored in the nearly calcium-free cytosol with calcium coming from the periphery or any other calcium source of the cell. Thus the calcium/calmodulin system is part of a storage power station of the cell.

In the pumping process based on the calcium transfer by calmodulin the lowest calcium concentration is set by the spontaneous dissociation of the calcium/calmodulin complex. This is consistent with the assumption made above to evaluate the upper limit of the free energy production by the calcium-loading of calmodulin.

If a sustained stimulation results in a sustained reaction of the cell, the detour, via the cytosol, in the transport of calcium-loaded and calcium-free calmodulin between the adenylate cyclase complex and the ATPase complex may be avoided. So the calcium cycling in the membrane region, described in [4] will be established.

An increase in the concentration of calcium-loaded calmodulin in the cytosol not only starts the pumping process mentioned above but also activates phosphodiesterase which, as is well known, destroys cAMP by hydrolysis [2].

The main difference in the new concept as compared to the former models is seen in the fact that it attributes to calcium not only the function of a messenger but also the function of a trans- porter for the free energy needed to start endergonic reactions. The transfer of free energy by calcium does not need to be restricted to the production of cAMP for the initiation of chemical reactions. It can be expected that also for other endergonic processes in the cell, e.g., for the generation of mechanical work the transfer of free energy by calcium is of importance.

Received January 9, 1990

1. Sutherland, E. W.: Angew. Chem. 84, $1117(1972)$

2. Cheung, W. Y.: Sci. Am. 246, 48 (1982)

3. Carafoli, E., Penniston, J. T.: ibid. 253, $50(1985)$

4. Alkon, D. L., Rasmussen, H.: Science 239, $998(1988)$

5. Stryer, L.: Biochemistry, p. 810. San Francisco: Freeman 1975

Naturwissenschaften 77, 177-179(1990) (C) Springer-Verlag 1990

\title{
Activated State in the Lepidocrocite Structure During Thermal Treatment
}

\author{
A. U. Gehring \\ Institute of Water Resources and Water Pollution Control (EAWAG), \\ Swiss Federal Institute of Technology (ETH), Zürich, CH-8600 Dübendorf \\ R. Karthein \\ Laboratorium für Physikalische Chemie der ETH, CH-8092 Zürich
}

\section{A. Reller}

Institute for Inorganic Chemistry, University of Zürich, CH-8057 Zürich

In natural environments such as soils and sedimentary iron ores ferric(oxy)hydroxides are major components [1, 2]. Upon heating to approximately $500-700 \mathrm{~K}$, e.g., during forest and bush burning or metamorphic processes, these compounds convert to ferric oxides. The structural and morphological changes during the conversion have been considered in the literature $[3,4]$. The reaction mechanism on an atomic level as a function of temperature, which gives insight into thermal conversion processes in natural environments, has not been reported yet. The transformation of lepidocrocite $(\gamma$-FeOOH), a ferric(oxy)hydroxide often found in soils, to the ferric oxide maghemite $\left(\gamma-\mathrm{Fe}_{2} \mathrm{O}_{3}\right)$ during thermal treatment is examined in this study.

The orange colored lepidocrocite under investigation was synthesized by oxidation of a $0.5 \mathrm{M} \mathrm{FeCl}_{2}$ solution (Merck p.a.) with $\mathrm{NaNO}_{2}$ after the method described in [5]. The precipitate was washed from the electrolytes with bidistilled water, stored at about $\mathrm{pH} 7$ for 90 days, then filtered and dried in an oven at $313 \mathrm{~K}$.

The synthetic lepidocrocite was identified by XRD. The thermal behavior was investigated by differential scanning calorimetry and thermogravimetry (DSC/TG). The course of the thermogravimetric measurements shows a well-defined change of weight due to loss of stoichiometric $\mathrm{H}_{2} \mathrm{O}$ between 470 and $520 \mathrm{~K}$. This dehydration process appears in DSC as a maximum endothermal effect indicating the conversion of lepidocrocite into maghemite. In addition to this endothermal peak, a broad exothermal peak is observed between 400 and $450 \mathrm{~K}$. In order to find structural and morphological evidence for this exothermal process, high-resolution electron microscopy (HRTEM) and electron diffraction were carried out. Under the HRTEM lepidocrocite shows lathshaped idiomorphous crystallites (Fig. 1a). The electron diffraction pattern of the crystallites reveals the presence of crystalline particles (Fig. 1b). Under prolonged irradiation by the electron beam the lath-shaped lepidocrocite can 

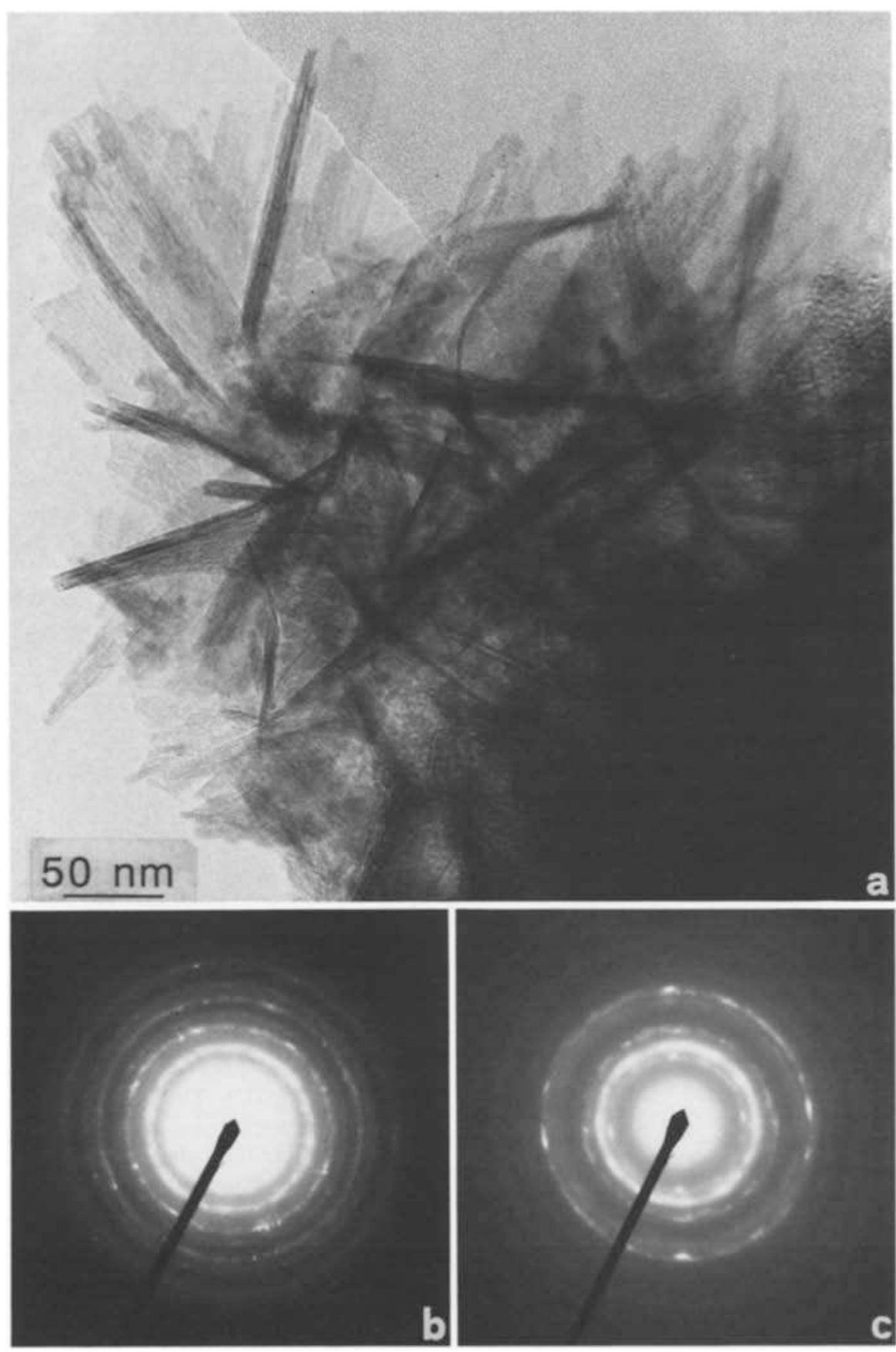

Fig. 1. a) Electron micrograph of lepidocrocite crystallites with lath-shaped morphology. b) Corresponding electron diffraction pattern providing the lepidocrocite structure. c) Electron diffraction pattern of maghemite obtained by prolonged irradiation of lepidocrocite crystallites

be transformed into pseudomorphous maghemite (Fig. 1c). This conversion indicates a rearrangement of the lepidocrocite structure on a microcrystalline level. Furthermore, this finding suggests that the lepidocrocite is highly activated before the actual dehydration takes place. This activated state can be attributed to the exothermal peak found by DSC between 400 and $450 \mathrm{~K}$. Since this exothermal process is not caused by fundamental morphological changes nor by significant weight loss, i.e., compositional changes, the

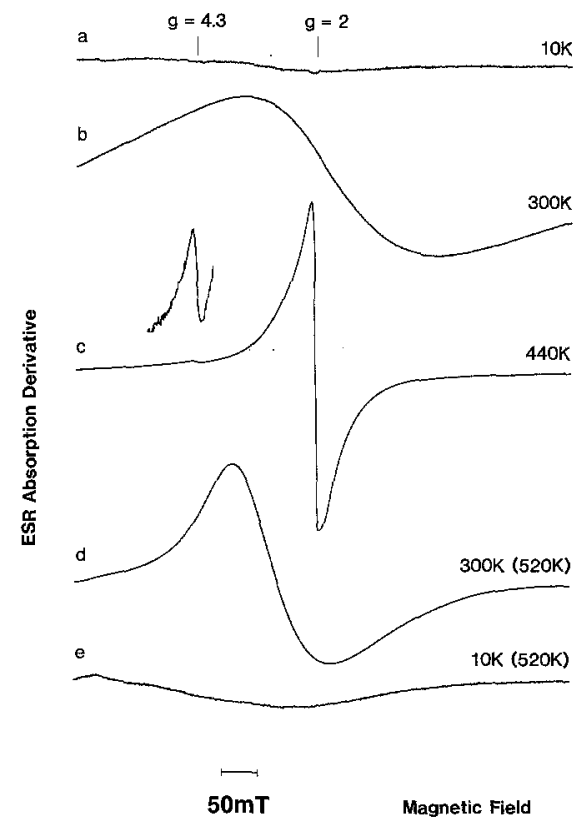

Fig. 2. ESR spectra of a lepidocrocite sample measured at a) $10 \mathrm{~K}$, b) $300 \mathrm{~K}$. Spectrum c) was taken of a lepidocrocite sample heated at $440 \mathrm{~K}$ for $0.5 \mathrm{~h}$, measured at this temperature and gain-reduced by a factor of 0.1 . In addition, the $g=4.3$ signal is displayed on the same scale as the above spectra. In d) and e) the lepidocrocite sample was heated to $520 \mathrm{~K}$, annealed for $0.5 \mathrm{~h}$ and then measured at 300 and $10 \mathrm{~K}$, respectively. Spectrum d) is gain-reduced by a factor of 0.01

structural rearrangements within the lepidocrocite have to take place on an atomic level.

Electron spin resonance (ESR) spectra have been recorded at X-band using $100-\mathrm{kHz}$ field modulation during the conversion of lepidocrocite into maghemite. At room temperature (RT) lepidocrocite is paramagnetic and shows a broad ESR signal with a line width of $250 \mathrm{mT}$ and a zero-crossing near a $g$-value of 2 (Fig. 2b). This broad line width is mainly caused by the electron spin-spin interaction between the $\mathrm{Fe}^{3+}$ ions within the [001] layers made up of edge-sharing $\mathrm{FeO}_{6}$ octahedra [6], and by the particle size and morphology of the lepidocrocite [7]. Magnetic ordering in the lepidocrocite beginning below the Néel temperature leads to a drastic decrease of the ESR signal intensity and at $10 \mathrm{~K}$ the signal disappears (Fig. 2a). Upon heating of the lepidocrocite in the ESR cavity two narrow signals evolve simultaneously at $410 \mathrm{~K}$, a strong peak at $g=2$ and a 
weak one at $g=4.3$. Low-temperature measurements before heating (Fig. 2a) exclude that the broad lepidocrocite spectrum masks the weaker $g=4.3 \mathrm{sig}$ nal. With increasing temperature, however, both narrow signals become more pronounced (Fig. 2c). These new signals superimpose the lepidocrocite signal found at RT and dominate the ESR spectrum. After heating to $520 \mathrm{~K}$ the strong peak shifts slightly from $g=2$ to about $g=2.5$. Furthermore, the line width broadens to $140 \mathrm{mT}$ and the intensity of the signal increases significantly (Fig. 2d). When cooling down to $10 \mathrm{~K}$ the intensity decreases and only a very weak signal can be measured (Fig. $2 \mathrm{e}$ ). The occurrence of the $g=2$ signal above $410 \mathrm{~K}$ can be interpreted as a consequence of maghemite formation and therefore of the beginning conversion process. The correlation with HRTEM observations suggests that this signal can be attributed to pseudomorphic maghemite. The strong increase of the ESR signal at $g=2$ above $410 \mathrm{~K}$ indicates the disintegration of the lepidocrocite structure before the main evolution of water detected by TG occurs. The onset of this process explains the broad exothermal peak found by DSC. At $520 \mathrm{~K}$ where the maximum endothermal effect is observed, the resonance field changes only little, but a drastic increase in the line width and a maximum intensity of the ESR signal are detected. It is well established that the magnetic properties of ferric oxides are dependent on the crystallinity [8]. Furthermore, the ESR line shape can be strongly influenced by the domain structure of the ferric oxides [9]. There-

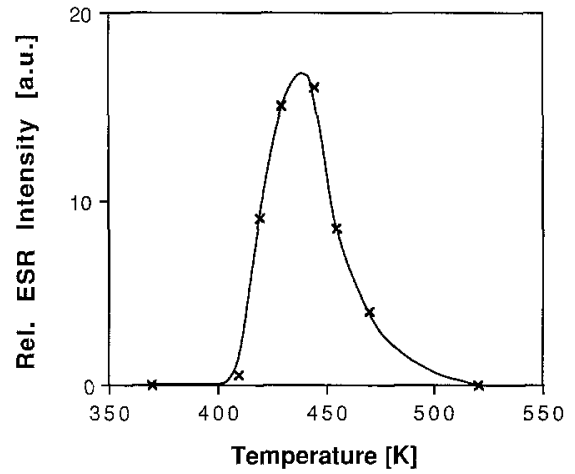

Fig. 3. Temperature vs. relative intensity in arbitrary units of the ESR signal at $g=4.3$

fore, it is very likely that the observed change in the $g=2$ ESR signal is mainly caused by the growth of ferrimagnetic maghemite crystallites during the thermal treatment.

The $g=4.3$ signal is characteristic for $\mathrm{Fe}^{3+}$ ions in distorted coordination polyhedra of rhombic symmetry [10]. The occurrence of this signal at $410 \mathrm{~K}$ indicates a rearrangement within the lepidocrocite structure on an atomic level. The temperature dependence of the $g=4.3$ signal reveals a maximum intensity at $450 \mathrm{~K}$ and a subsequent drop to zero at $520 \mathrm{~K}$ (Fig. 3). This suggests that the structural reaction refers to an intermediate change of the $\mathrm{Fe}^{3+}$ coordination before the actual evolution of water, i.e., the condensation of water molecules. Regarding the lepidocrocite crystal structure with hydrogen interlinking the [001] layers [6] and the conversion mechanism leading to the condensation of water molecules, the $g=4.3$ signal is explained as an enhanced distortion of $\mathrm{FeO}_{6}$ octahedra due to the dynamic rearrangement of the positions of the oxygen and hydrogen atoms.

This result leads to the conclusion that ESR spectroscopy defines and characterizes an intermediate activated state of the lepidocrocite structure prior to the actual formation of crystalline maghemite.

The authors would like to thank $G$. Bondietti (EAWAG) for providing the lepidocrocite sample. This project was supported by the Swiss National Foundation project No. $2.942-0.88$ and a grant of the Board of the Swiss Federal Institute of Technology.

Received October 23, 1989 and February 5, 1990

1. Schwertmann, U., in: Iron in Soils and Clay Minerals, p. 267 (Stucki, J. W., et al., eds.). Dordrecht: Reidel 1989

2. Gehring, A. U.: Geol. Soc. Spec. Publ. 46, $133(1989)$

3. Gómez-Villacieros, R., Hernán, L., Morales, J., Tirado, J. L.: J. Coll. Interf. Sci. 101, 392 (1984)

4. Hedley, I. G.: Phys. Earth Planet. Inter. 1, 103 (1968)

5. Glemser, O.: Ber. dtsch. chem. Ges. $71,158(1938)$

6. Christensen, H., Christensen, A. N.: Acta Chem. Scand. A32, 87 (1978)

7. Kraan, A. M. van der: Phys. stat. sol. a $18,216(1973)$

8. Murad, E., Schwertmann, U.: Miner. Mag. 48, 507 (1984)

9. Griscom, D. L.: J. Non-Cryst. Solids 68, 81 (1984)

10. Calas, G.: Rev. Miner. 18, 513 (1988)
Naturwissenschaften 77, 179-182(1990) C Springer-Verlag 1990

\section{Änderungen der Serumparameter eines amphibisch lebenden Wirbeltieres}

\section{Bioindikatormodell zum Nachweis von Strahlenbelastung}

\author{
M. Giannetti, H. Strick, A. Trux und W. J. Kloft \\ Institut für Angewandte Zoologie der Universität, D-5300 Bonn
}

Bei der kontinuierlichen Zunahme einer anthropogenen Strahlenexposition der Ökosphäre durch steigende Nutzung von Kernspaltungen für friedliche und militärische Zwecke kommt der Ab- schätzung des Strahlenrisikos besondere Bedeutung zu [1]. Biologische Indikatoren für radioaktive Kontaminationen von Ökosystemen können physikalischen oder chemischen Detek- tionsverfahren überlegen sein, wenn sie Belastungen auch im niederen Dosisbereich (mit sensiblen physiologischen Parametern) und auch noch lange Zeit nach der Strahlenbelastung (u.U. mit vererbbaren Parametern) anzeigen. Aufbauend auf den Arbeiten von Strick et al. [2, 3] wird ein Zeigermodell entwickelt, das diesen Anforderungen genügt: Der Indikatororganismus muß schnell, irreversibel, reproduzierbar, signifikant und im Idealfall auch noch durch Weitergabe an Nachkommen auf eine Noxe reagieren.

Als Zeigerorganismus wurde der mit ${ }^{45} \mathrm{Ca}$ behandelte Südafrikanische Kral- 